IJAIM

24,4

318

\title{
Editorial
}

\section{Special issue on institutional and legal frameworks, corporate reporting and managerial performance in emerging markets}

Institutional and legal characteristics such as governance corporate mechanisms, ownership structure, the nature of contracting, investor and creditor protection and the state of capital market development play a vital role in corporate reporting and managerial performance. It has been acknowledged in the literature that ownership structure, political connections and social networks may either distort or facilitate institutional and legal frameworks, thus affecting accounting and reporting practices in both private and public entities. This special issue adds to the limited theoretical and empirical research focusing on these important aspects in emerging countries.

\section{Contribution of the special issue papers}

This section briefly outlines the contributions of the papers published in this special issue under the following subheadings: political connections and firm performance, political connections and relation to earnings and audit quality, corporate social reporting in emerging economies and the role of industry concentration and disclosure in firm performance.

A number of the papers in this special issue relate to the implications of political connections. This is most welcome, as the extant literature in this area is far from settled, and there is evidence of mixed findings.

\section{Political connections and firm performance}

Cheema, Munir and Su investigate the association between political connections and firm performance using a sample of 250 non-financial firms in Pakistan. The study reports that political connections in Pakistan are common and finds a significant relation between political connections and firm performance, measured in terms of accounting returns. Interestingly, the negative association between political connections and firm performance is more pronounced in firms having connections with politicians, compared to those with connections to former government officials.

\section{Political connections and relation to earnings and audit quality}

Imam and Nowland examine whether the earnings quality of politically connected firms is affected by changes in political stability and government effectiveness in Indonesia. Based on a sample of 2,073 firm-year observations in the period from 2003 to 2012, the study finds that increased government effectiveness reduces the benefits of political connections and increases earnings quality. However, increased political stability is associated with lower earnings quality, that the authors attribute to enhanced certainty of benefits from political connections, reducing the need for politically connected firms to be responsive to market pressures. 
Khan, Mihret and Muttakin examine the association between firms' political connections and agency cost and also explore the potential moderating effect of audit quality on the aforementioned association. They show that politically connected firms have higher agency costs than firms with no connections, and that audit quality moderates the relationship between political connection and agency costs. The study highlights the importance of audit quality in mitigating agency problems in emerging economies.

El-Helaly investigates the relationship between related party transactions (RPTs) and accounting quality in firms listed on the Athens Stock Exchange. The study compares accounting quality between a group of firms that engage in material RPTs and a second group of firms that do not engage in material RPTs. Their results do not suggest that firms with significant RPTs exhibit less accounting quality than non-RPTs firms. This is consistent with RPTs being considered conventional business transactions rather than a vehicle for opportunism.

\section{Corporate social reporting in emerging economies}

Young and Farley investigate the extent to which international and domestic guidelines have influenced the content of corporate environmental reporting (CER) in China. The first nationwide guidelines on Open Government Information (OGI) and Open Environment Information (OEI), introduced in 2008, provide an interesting experimental setting. $\chi^{2}$ test statistics are used to analyse the significance of differences in reporting items supported by Chinese guidelines versus those supported by international reporting guidelines only. The study shows partial convergence in climate change reporting co-existing with China specific interpretations. The authors argue that coercive nature of the Chinese Government's guidance in OGI and OEI led to the rapid growth of CER.

In a qualitative study using semi-structured interviews, Hossain and Alam investigate the organisational accountability of less economically powerful stakeholders in the absence of formal corporate social reporting (CSR) guidelines in Bangladesh. The stakeholders were representatives from non-governmental organisations, media, civil society, customers, regulators, trade union leaders and employees. Using the theoretical lens of accountability with administrative and institutional reforms, the findings of this study lead the authors to conclude that companies in Bangladesh have low levels of CSR with regards to stakeholder accountability and stakeholder engagements. They also argue for the need for mandatory CSR in Bangladesh.

\section{Industry concentration and disclosure on firm performance}

$\mathrm{Haw}, \mathrm{Hu}$, Lee and $\mathrm{Wu}$ contribute to the growing literature on the price-leading-earnings relation, industry concentration and corporate earnings quality by examining whether industry concentration affects investors' ability to anticipate future earnings. This is achieved through testing two channels, product market power and intra-industry information transfer, through which industry concentration affects the informativeness of stock returns about future earnings using a firm-level sample from 38 economies.

They find that industry concentration significantly enhances investors' ability to predict future earnings and also show that both product market power and intra-industry information transfer contribute to explaining the positive association 
IJAIM

24,4

320

between industry concentration and future earnings. They also show that the efficacy of a country's competition law diminishes the positive impact of industry concentration on future earnings by weakening the economic impact of the two underlying channels.

Nahar, Jubb and Azim examine the relationship between risk disclosure, cost of equity capital and performance of all 30 Bangladeshi banks listed on the Dhaka Stock Exchange during the period 2006-2012. They find that the cost of capital is negatively associated with risk disclosure, and this is consistent with the argument that reduction of information asymmetry reduces cost of capital. They also report an inverse relationship, albeit weak, between risk disclosure and bank performance. Based on their findings, they suggest that financial institutions improving risk disclosure in emerging countries may reduce their cost of capital.

Over the past two decades, there have been many studies that examined the role of connected transactions on firm performance and earnings quality. As these issues are contentious, there have been mixed results, as some researchers find that politically connected and related party transactions are used for opportunistic purposes and affect firm performance adversely. Others find connected transactions occur for genuine operational purposes that lead to efficient resource allocation and better performance, not only among the connected firms but also benefit national economies. We note that there is a dearth of studies that rigorously examined the implications of connected transactions besides discretionary accruals, firm performance, cost of debt and cost of equity (Chaney et al., 2011; Boubakri et al., 2012). Firm-level implications may be examined from the point of view of investment efficiency, institutional ownership and the cost and benefits when connections become weaker subsequent to change in government or other structural change. From a macro perspective, the effect of connections on foreign direct and indirect investments may also be examined.

Kamran Ahmed

Department of Accounting, La Trobe University, Melbourne, Australia, and

Paul Mather

La Trobe Business School, La Trobe University, Melbourne, Australia

\section{References}

Boubakri, N., Guedhami, O., Mishra, D. and Saffar, W. (2012), "Political connection and the cost of equity capital”, Journal of Corporate Finance, Vol. 18, pp. 541-559.

Chaney, P.K., Faccio, M. and Parsley, D. (2011), "The quality of accounting information in politically connected firms", Journal of Accounting and Economics, Vol. 51 Nos 1/2, pp. 58-76. 